Canadian University Music Review

Revue de musique des universités canadiennes

\title{
Developmental Phases in Selected British Choirs
}

\section{Estelle R. Jorgensen}

Numéro 7, 1986

URI : https://id.erudit.org/iderudit/1014093ar

DOI : https://doi.org/10.7202/1014093ar

Aller au sommaire du numéro

Éditeur(s)

Canadian University Music Society / Société de musique des universités

canadiennes

ISSN

0710-0353 (imprimé)

2291-2436 (numérique)

Découvrir la revue

Citer cet article

Jorgensen, E. R. (1986). Developmental Phases in Selected British Choirs.

Canadian University Music Review / Revue de musique des universités

canadiennes, (7), 188-225. https://doi.org/10.7202/1014093ar

All Rights Reserved @ Canadian University Music Society / Société de musique des universités canadiennes, 1986
Ce document est protégé par la loi sur le droit d'auteur. L’utilisation des services d'Érudit (y compris la reproduction) est assujettie à sa politique d'utilisation que vous pouvez consulter en ligne.

https://apropos.erudit.org/fr/usagers/politique-dutilisation/ 


\title{
DEVELOPMENTAL PHASES IN SELECTED BRITISH CHOIRS
}

\author{
Estelle R. Jorgensen
}

\section{INTRODUCTION}

In an earlier article 1 I outlined a conceptual framework for five developmental phases in amateur ensembles, or phases that typify the "life cycle" of ensembles; namely, formation, expansion, maturation, regression and cessation. Each phase was sytematically described with reference to temporal, spatial, numerical, causal, ethical and aesthetic dimensions. Aspects of each of these dimensions were theorized to vary among the phases and constitute distinct profiles of each phase.

In the present study, two propositions derived from this framework were tested: first, in general terms, whether the notion of distinct phases of development more-or-less holds in the real world; and second, whether more specifically, the distinct characteristics that were predicted to constitute each of the developmental phases are also moreor-less evident in the real world. This article, therefore, directly follows the above-mentioned theoretical piece and can usefully be read in conjunction with it.

Eight historical cases of British amateur choirs, each covering periods of between two and ten decades were studied: Huddersfield Choral Society (1836-1936), Windsor and Eton Choral Society (1841-1941), Glasgow Choral Union (1843-1943), Bradford Festival Choral Society (1856-1906), Edinburgh Royal Choral Union (1858-1958), South

1 Estelle R. Jorgensen, "On the Recruitment Process in Amateur Ensembles," Canadian University Music Review 6: 293-318, 1985. 
London Choral Association (1869-1890), Glasgow Orpheus Choir (1906-1951), and Croydon Philharmonic Society (1914-1954). Each account represents the choir's view of itself as seen through the eyes of an individual intimately associated with it at a given point in time. The choirs were selected because they were diverse with regard to their eminence (e.g. regional, national, or international reputation), their history and their geographical location. ${ }^{2}$

In order to identify phases of development and specific characteristics in each phase, I examined local historical accounts of each choir and the important elements emerged following intuitive inspection of the evidence. This approach is justified for two reasons: first, developmental phases can best be distinguished over the long term by comparative and descriptive means; and second, they are formulated at a high level of generality and most appropriately studied from a phenomenological perspective. A case study approach using historical accounts reflecting the choir's view of itself is consistent with this point of view. The evidence is not without its limitations: for instance, the possible suppression of information deleterious to the choir's reputation, and the differing objectives of the choir histories or accounts. Some were written, for example, to celebrate jubilees and centenaries, making it difficult to study regression and cessation. Nevertheless, it is possible to point to documentary evidence supporting the concept of distinctive phases.

2 The Huddersfield Choral Society, Windsor and Eton Choral Society, Bradford Festival Choral Society, Edinburgh Royal Choral Union, and Croydon Philharmonic Society are listed as members of the National Federation of Music Societies in the Register of Members and Handbook, 1984. The Register may be obtained from the National Federation of Music Societies, Francis House, Francis Street, London, SW1P 1DE, U.K. 


\section{CASE STUDIES}

I will now describe the evident temporal, spatial, numerical, causal, ethical and aesthetic aspects of the developmental phases for each of the eight choirs. The objective is not to provide a chronological account of each choir's development but rather to briefly sketch an historical overview and then focus on aspects of time, space, number, causation, ethics, and aesthetics in turn, showing how they varied in each developmental phase.

\section{Huddersfield Choral Society (1836-1936) ${ }^{3}$}

The Huddersfield Choral Society was constituted in 1836 as a "musical club" for the benefit of members; its formation marked the culmination of a six-year period during which a loosely organized group of musicians met for "vocal and instrumental practise" (Wilmhurst [1936]: 6). Following a somewhat limited and slow expansion, the Society grew more rapidly during the Joshua Marshal regnum (1876) with an even more rapid growth and consolidation to attain a national reputation during the Henry Coward era (1901-31). By the Malcolm Sargeant period, commencing in 1932, the Society had attained maturation.

At formation, rehearsals were held monthly on Friday nights. By maturation in 1936 they were held weekly and Friday nights were regarded as "Choral nights", "sacrosanct from other engagements". Also, performances were held quarterly at formation but during expansion in 1876 a policy of three concerts a year was instituted and continued until 1936 (ibid.: 6, 7, 17, 22).

Similarly, less change in performance venues is evident during the choir's mature phase. Performances were initially given in the Philosophical Hall (1836-67) and moved during expansion to the Queen

3 W.L. Wilmhurst, comp., Huddersfield Choral Society Centenary Memorial, 1836-1936. Huddersfield: W.H. Cook Ltd., n.d. [1936]. 
Street Schools (1867-73), the Armoury (1873-81), and eventually to the Town Hall (1881-1936) where they continued to be held in maturation. W.L. Wilmhurst (ibid.: 25,35 ) attributes the Society's growth, in part, to the establishment of a Town Hall reflecting the growth of Huddersfield and providing a venue for the choir's performances from 1881 during expansion.

The Society membership increased significantly during expansion. At formation it numbered 16 men. The following year it totalled 62 members (eight women and 54 men). By 1842 it numbered 79 (14 women and $65 \mathrm{men}$ ), rising to over 250 in 1881 and 450 in 1885. By maturation in 1936 it had consolidated to 329 members - 214 women and 115 men (ibid.: 6, 7, 25, 35). The choir membership changed over the period from a majority of men to a majority of women, a fact that may relate to performance practice changes and social factors external to the choir.

There were also changes in community interest in the ensemble and in its image and prestige. At formation, rather than give public performances, the Society held "meetings" principally for the benefit of its members and discouraged wider community involvement than that from Huddersfield itself. Public support increased during expansion, witnessed by the increase in subscriber lists during Marshall's conductorship (1876-85). By maturation the interest in its performances had broadened from local and regional to national exposure and attention. At formation, the Society was preoccupied with defining itself and establishing its reputation (i.e. with personification), exemplified by the drawing up of a written constitution in 1836 followed by another in 1842. This contrasts with the Society's later concern in 1931 with maintaining its reputation (i.e. with image preservation), illustrated in the search for a successor to Coward who would maintain the Society at the high level to which it had become accustomed. Also, the Society's prestige rose slowly, increasing to the Coward era (1901-31) during which it rose to its "maximum attainment" (ibid.: 25. Also see pp. 14, 
22, 29) and to the reputation it had acquired among English Choral Societies.

Changes in the Society's values, rules and orientation to change are also evident. The initial constitution was formulated by working class people who were devoted to "concerted music" and wished to educate themselves. It was organized as a Joint Stock Company in which all the members had a financial stake. As such, it served the local community and social values formed its raison d'etre. During expansion, the joint stock concept was rescinded, middle and upper class people formed a greater proportion of the membership and the Society's "character and methods" altered significantly. The change in the rules by which the Society operated is exemplified by constitutional changes over the period in purview. At formation, each member in rotation was entitled to select the repertoire whereas in 1842 a committee was set up for this purpose. Also, after 1842 regular records and minutes of meetings were kept. There were two periods during expansion - the Marshall (1876-85) and Coward (1901-31) eras - when the Society was particularly oriented toward change in performance venue, ensemble size and vocal technique. In contrast, by 1936, during maturation, the "stationariness" of the Society and its orientation toward stability and consolidation was recognized (ibid.: 6, 7, 10-12, 15, 17, 22-25, 30).

The artistic standards of the Society changed significantly from formation to maturation. In formation, programmes mainly consisted of selections from major works in contrast to the performance of entire works by maturation. Local singers comprised the soloists at formation whereas the practice of contracting professional singers was established by 1876 during expansion. A widening repertoire is also evident over the period. W.L. Wilmhurst attributes the "crescendo" of Society development and the growth in its artistic standards to two factors: the influence of the conductors (principally Robert Senior Burton, Marshall, and Coward who each built on the work of their predecessors), and the increasing musical expectations of the audiences (ibid.: 12, 14, 15, 22, 25, 26, 29, 39, 40). 


\section{Windsor and Eton Choral Society (1841-1941) ${ }^{4}$}

As early as 1836 , George Elvey attempted to found a choral society but the group failed after two years. It was reconstituted, again under Elvey's direction, as the Windsor and Eton Amateur Musical Class (1841), changed to the Windsor and Eton Amateur Musical Society (1844), and then to the Windsor and Eton Choral Society, a name it continued to hold from 1849. Considerable instability in its development is evident. A slow expansion continued until about 1861 when regression set in, followed by rejuvenation and slow expansion from 1866 that lost momentum then continued under Samuel Smith from 1882 until the late 1880s when regression again set in. Rejuvenation under Walter Parratt's regnum (1891-97) was followed by regression to the brink of dissolution in 1901 but rejuvenation and expansion during the Bernard Everett era (1903-32) revived the fortunes of the Society. By 1941 it had established a regional reputation.

At first, the Society's performances appear to have been relatively irregular. There were often four concerts a year during the first 50 years but in the Parratt regnum a pattern of three concerts per year and then two was part of the process of rejuvenation. During periods of regression, performances appear to have been more irregular, witnessed by the cancellation of the final concert in the 1890 season (the last in the Smith era) for lack of member attendance at rehearsals. A pattern of weekly rehearsals seems to have developed by 1870 , during expansion and for many years practises were held on Monday nights. Extraordinary circumstances during World War II necessitated a change to Sunday afternoon rehearsals (ibid.: 16, 21, 22, 25, 33).

Instability is also evident in performance and rehearsal venues. Over the period 1850-60 during early expansion, performances took place in the Windsor Town Hall which was ill lit, poorly ventilated and had in-

4 Mervyn Bruxner, A Hundred Years of Music-Making: a History of the Windsor and Eton Choral Society, 1841-1941 Windsor: Oxley \& Son, 1941. 
sufficient space for performers and audience. From 1867, performances were in St. Mark's School (the only large hall in Windsor at the time) and after 1880 in the Albert Institute where they continued to be held for the next 40 years. While the Albert Institute represented an improvement in venue, it was still inadequate. The Society also found itself without a permanent rehearsal venue in the 1860s and 1870s - a period of regression in the early 1860 s and slow rejuvenation that appeared to falter in the late 1870s. In 1933 rehearsals moved to the Music School at Eton College where cheaper but more suitable facilities were available; this caused greater hardship for the Windsor members but was more attractive for the Slough members so that by 1941 the latter constituted more than half of the Society membership. As well, in early expansion during the period of the 1850 s, it faced competition from the Windsor Madrigal Society (also conducted by Elvey and Parratt) whose members considered themselves socially superior to the Windsor and Eton Choral Society. Concerts of the two societies clashed. During regression in the 1860 s and again in the 1880 s, Windsor and Eton Choral Society members left to join the rival choir and subscriptions were deflected (ibid.: 12, 13, 17, 33).

Instability in the Society's membership is also evident. At formation in 1841 there were 50 members augmented by choristers from St. George's Chapel, Windsor, but during regression in 1864 rehearsal attendance fell to 14 . Twenty young women joined the Society in 1874 - a novelty in those days - and attendance increased that year. Membership fell again during regression to 40 in 1891 but later rose in expansion during Parratt's regnum from 80 in his first year to 100 in his last. It numbered 92 in 1902 and 162 in 1930 (ibid.: 17, 18, 25, 28).

Changes in community interest in the Society, its image and prestige are also evident (see ibid.: 9, 11, 12, 17, 20, 28, 29). Despite royal patronage during 1846-1923 from Prince Albert (1846-61) and Princess Christian of Schleswig-Holstein (1866-1923), it had still not captured the imagination of the community after 44 years and interest in its performances centred on the soloists rather than the choir. During 
rejuvenation in the period 1903-32, Everett set about increasing community interest in the Society by entering it for competitions, changing its performance venue, spending lavishly on first-rate soloists and large orchestras, supporting charities with concert proceeds, holding socials and parties, and "browbeating" his friends, among other means. He succeeded in drawing attention to the Society, raising community support for it and increasing the subscriber list from 60 to 230. In formation and early expansion it was concerned with establishing an image, examplified in several name changes. Even as late as expansion during the Everett era, it was still preoccupied with reestablishing an image in the community and redefining itself. Its fortunes seem to have been very much bound up with the conductor's prestige and his commitment to the Society and it continued, in the main, to be conducted by prominent individuals who were closely associated with church music. Its founder, Elvey, was organist of St. George's Chapel, Windsor, during the first three decades of the twentieth century; its rejuvenation and expansion were closely linked to the efforts of Everett, a clergyman and musical amateur, and later, conductor Mervyn Bruxner's connection with Eton College enabled the Society to take advantage of rehearsal facilities there from 1933.

The Society was founded to serve both religious and musical values; to improve church music and develop good musical taste among the "tradesmen and working classes of Windsor and Eton" (ibid.: 9-12, 25, 29). A "universalistic" philosophy, illustrated by the fact that Elvey collected about 50 singers who knew little about music, prevailed at formation. Over time, the focus narrowed to emphasize musical values; this is paralleled by the expansion of repertoire, improvement in quality of soloists, and increase in orchestra size during the latter half of the century.

Artistic standards over the first half-century may be contrasted with those over the second half-century, especially under Parratt (1891-97) and Everett (1903-15 and 1919-32). For the first 30 years there was a limited repertoire (less than 60 works of which 35 were not performed 
more than twice) with works by Handel predominating. Early concerts consisted of oratorio selections and light music (including glees, songs, and instrumental solos). Under Parratt, the number of concerts per year was reduced to two (one miscellaneous concert and one oratorio performance) and the repertoire was extended. Until 1884, Society performances were augmented by choristers from St. George's Chapel, lay clerks from Windsor, and soloists drawn from the Chapel choir, as well as instrumentalists from the private royal orchestra and regimental ensembles. Under Everett, the quality of soloists was improved and the orchestra size increased (ibid.: 8, 11-13, 22, 25, 27, 36, 37).

\section{Glasgow Choral Union (1843-1943)}

The Glasgow Choral Union originated as the "Society to perform the Messiah" founded in 1843 as a result of the efforts by members of a men's glee club. ${ }^{6}$ The Society expanded quickly and rapidly, acquiring a national reputation by $1881 / 2$ and receiving international recognition in its mature phase.

The Society's development during expansion is evidenced in the decreasing amount of time required to prepare a performance and the increasing number of performances given annually. At formation it took 20 rehearsals to prepare the first performance of the Messiah in April, 1844, under the conductorship of Thomas Macfarlane, then organist of St. Jude's Episcopal Church. 220 performances were given by 1882; 62 in the first 20 years, 64 in the next ten years and 94 in the following nine years. Performances were also consolidated into "seasons" so that

5 Robert Craig, comp., A Short History of the Glasgow Choral Union Glasgow: Robert Maclehose and Co., n.d. [1944].

6 Craig does not clarify the length of time the men's glee club had been in existence prior to 1843 stating, rather, that a "number of gentlemen had been in the habit of meeting in Nicol's Coffee House at 179 Argyle Street for the purpose of singing glees." (p. 15). 
by 1919-43, during maturation, an annual regular concert season from November to March had emerged (ibid.: 13, 14, 16, 32).

By maturation, the Union had formalized a feeder system for recruitment of new members. In the 1920s, as a result of the efforts of its conductor, Wilfrid Senior, the Union, in cooperation with the educational authority in Glasgow started a class in sightreading, voice production, and choral singing. By 1927/8 these high school classes were flourishing and providing a steady stream of recruits for the Union. Also, during expansion, it faced competition from the rival Glasgow Harmonic Society and this was solved in 1855 when the two merged to form the Glasgow Choral Union. 7 Later, in 1891, as it approached maturation, the Union again faced competition from the rival Scottish Orchestra Company Limited. Once again it solved this problem by an agreement in 1895 which led to union in 1898. When the Orchestra finally withdrew from this Union, a suitable accommodation was again reached (ibid.: $39,42,44,51$ ).

Within a year of formation the choir attained the numerical strength that characterized it over much of the period until the 1898/9 season. At formation it numbered 176 (49 women and 127 men) but by December, 1844 it totalled 400 . There were 405 members (202 women and 203 men) in its jubilee year and 294 members (168 women and 126 men of whom 14 women and 23 men were listed as "Absent on Service") in its centenary season during wartime. The increase in the proportion of women in the choir over the ten decades doubtless reflected social changes external to the choir and changes in performance practice. At first, the alto was sung by men but as women began to sing alto in increasing numbers, the section was mixed (e.g. in the 1868/9 season the alto section consisted of ten women, five men and seven

7 Craig (pp. 23, 24) claims that "the leading spirits" of the Hutcheson and Southern Musical Associations had "graduated" from the Glasgow Musical Association, suggesting that these choirs were in part at least, offshoots from the Glasgow Musical Association. 
boys) and later, entirely composed of women (ibid.: 10-12, 16, 17, 26, $33,34,38,39,43,46)$.

Community interest and support for the choir was cultivated throughout expansion by its participation in benefit concerts. There was an audience of 1764 at its first concert in 1844, its performances in November, 1852 "went far to establish the Society in public favour" and its performances in the Music Festival of 1860 further directed community attention to it. Benefit concerts were also given in 1873, 1879 , and in the $1915 / 16$ season. As well, the Union established links with senior civic officials, exemplified in the appointment in 1868/9 of E.Ewing, Lord Provost, as an honorary office bearer; this practice was continued through expansion and maturation. The Union's contribution to the City was rewarded, in turn, by community support for the choir. In formation and early expansion the Society was principally concerned with choosing a name and establishing a reputation. As noted above, it was first known as the Society for performing the Messiah. Subsequently, it was called the Glasgow Musical Association in 1844, a name it held until 1855 when it united with the Glasgow Harmonic Society to form the Glasgow Choral Union. The extension of this union to incorporate the Scottish Orchestra in 1898 resulted in a further change of name to the Choral and Orchestral Union of Glasgow. As it moved through expansion to maturation the Union became more involved in preserving its image and in spite of difficulties it faced in the mid-1890s, "it never fell from the high place it occupied". Further, its prestige rose during expansion as it became recognized as the senior choir in Glasgow in the mid-1850s and a national institution by 1877 , and it opened the $1881 / 2$ season "with a feeling that the climb was ended and the hill-top reached." By 1901 it was recognized as a premier choral society and international recognition was accorded the Union in 1911 with an invitation to the Paris International Music Tournament (ibid.: 29, 32, 43, 47, 53). 
The choir's repertoire expanded from the Messiah to include major choral-orchestral works; orchestral concerts were also sponsored from 1874 to 1898 but subsequently, the focus again narrowed to the performance of major choral and choral-orchestral works. As the objectives changed, they were formalized in rules, for example, the rules of union with the Scottish Orchestra in 1898. The changes in objectives during early expansion engendered conflict among the members, for example, over the payment of professional soloists and the associated financial troubles in 1850. Also, the choir's solid development in formation and expansion was due, in large measure, to management by its executive. The choir appears to have been formally organized at an early stage and member cooperation was institutionalized early in expansion. Interestingly, the office-bearers are given more prominence in Robert Craig's account of the choir's development than are the conductors (ibid.: 16, 19, 27, 44).

Artistic standards also increased over the period from formation to expansion. Orchestral accompaniments improved. Until 1874 the choir was accompanied "either by a local 'scratch' orchestra or by orchestras engaged from other parts of the kingdom" (ibid.: 13, 14, 27, 38, 39, $41,42,44)$. Over the period $1874-98$ it benefitted from performances with a permanent orchestra that was increased to 90 musicians in $1891 / 2$ and arrangements for orchestral accompaniments were formalized at the time of the union with the Scottish orchestra in 1898. Not only was there an expansion of repertoire during the period but the emphasis moved from a mixture of major works and selections from them to the performance of complete major choral-orchestral works. The rise in artistic standards may be attributed to the musical direction of conductors including Julius Seligman (1851-57), H.A. Lambeth (1857-80), Chorus master Allan Macbeth (1880-86), Joseph Bradley (1887-1908), Henry Coward (1908-10), and Wilfrid Senior (1922-43). 


\section{Bradford Festival Choral Society (1856-1906) ${ }^{8}$}

The Bradford Festival Choral Society arose out of the Bradford festivals of 1853 and 1856 and was formed in 1856 at the instigation of the Festival Committee to provide its permanent choir. From the outset expectations of it were comparatively high and the newly formed choir had to match the level of expectation generated by the festival choirs of 1853 and 1856 . It expanded steadily and rapidly achieved some features associated with later expansion and maturation. Within its first 50 years of existence it attained maturation. By 1885 associates spoke of preserving its reputation and attracting conductors and composers of first rank by the $1895 / 6$ season (ibid.: $37,44,45,151,193$ ).

The notion of a concert season was somewhat different in formation and early expansion from that in maturation (see ibid.: 247-66). During the initial five years (1857-61) the number of concerts each year varied (with five, eight, four, three and five, respectively) settling down from 1868 to four or five performances a year. At first, the concert season was longer and less well-defined. The first five seasons (1856/7-1860/1), for example, ran from December to May, November to July, October to May, October to April, and September to April, respectively. It was later shortened and during maturation ran from November (or late October) till March (or early April) with the exception of special performances, for example, May 17, 1906, in Queen's Hall, London at the invitation of the London Philharmonic Society.

Stability in the performance and rehearsal venues over the period is evident (see ibid.: 17, 23, 107). St. George's Hall, completed in 1853, was available for choral-orchestral performances from the Society's formation. Also, rehearsals were held in the orchestra of St. George's

8 G.F. Sewell, $A$ history of the Bradford Festival Choral Society from its Formation in 1856 to its Jubilee in 1906. Including Also a Brief Account of the Origin of the Bradford Subscription Concerts and of the Bradford Permanent Orchestra, Bradford: G.F. Sewell, 1907. 
Hall from formation until the close of 1870 during expansion and then in the Mechanics Hall where they were still being held in 1906, some 25 years later.

There were changes in the Society's numerical strength and in the availability of places over the period from formation to maturation (see ibid.: $34,47,62,191,224)$. In 1858 there were 222 singers: 66 women (54 trebles and 12 contraltos) and 156 men (42 altos, 57 tenors, and 57 basses). By 1895 in maturation, there were over 300 singers with the soprano and alto parts sung by women and the tenor and bass parts sung by men, and an increased proportion of women in the ensemble. A system of first- and second-class memberships was instituted at formation in which a distinction was made on the basis of the members' knowledge of music and choral singing. Early in expansion, in 1858, the Society was invited to give a command performance at Buckingham Palace and the applicants at that time were so numerous that a resolution was passed admitting only first-class members and instructing second-class members to stand aside. There was a scarcity of sopranos at formation and early expansion and in January, 1857, it was recommended that no more basses and tenors be received into the Society at that time. During the following July the Society decided to admit ten basses, six tenors and an indefinite number of trebles and altos. This situation contrasts with that prevailing at maturation in 1906 where soprano and alto voices were abundant and tenor and bass voices were comparatively scarce - a circumstance doubtless due to changes in performance practice and social factors external to the Society

There were changes in community interest, morale, and prestige over the period. Before the command performance in 1858 early in expansion referred to above, "the breast of every member was fired with enthusiasm and anxious expectation." There was great community interest in this event and some of the leading men of Bradford organized a local concert after the command performance had been given. The annual report of 1860 also reflected a high level of morale among the members. By 1885 , the Society was concerned to "preserve the good 
reputation enjoyed for so many years, not only in Bradford, but in many parts of the country." Later, the mounting dissatisfaction with Robert S. Burton's conductorship during 1886 culminated in the Annual Meeting of 1887 during which Burton was not reappointed because of expressed fears that the Society was in danger of regression - something that the members believed must be avoided at all cost. At the time of Burton's dismissal it was said: "There is nothing so delicate as reputation; and we shall have to watch jealously ... that that reputation we have gained is not lost." A "doleful, pessimistic tone" prevailed at the subsequent February, 1890, meeting because of the poor financial state of the Society. Some members were of the belief that the balance should be spent on "memorial cards, as they were getting to the end of their existence." The Society's prestige was enhanced by its association with musicians of first rank, for example, in the 1895/6 seasons, with Frederic H. Cowen, C. Hubert H. Parry, Charles Villiers-Stanford, and the Halle Orchestra. In 1897 the president approached Cowen to take the conductorship determined that they should have an eminent conductor and should be "in the very front rank of such Societies in the kingdom". The Society's prestige was further enhanced by the invitation to participate in a London Philharmonic Society concert in Queen's Hall, London, in 1906. G.F. Sewell attributes its expansion to the contributions of its various presidents, notably, Samuel Smith and Henry J. Mason whose financial contributions toward the payment of deficits, travel costs, and conductor expenses were important (ibid.: 53, $54,80,113,114,151,155,156,179,193,194,199,200,223)$.

The Society's initial objective was the "study and practice of vocal music." It was also to form the permanent choir for the triennial Bradford music festivals. During expansion, however, the focus narrowed to serve the interests of the Society rather than those of the Festival. While musical values were emphasized from the outset, the Society became progressively more elitist as expansion proceeded, exemplified in the rising standards of admission to membership over the period (ibid.: 44-46, 239). 
During its first 15 years the Society programmes consisted of partsongs, glees and madrigals alternating with familiar oratorios. With the advent of the subscription concerts organized in 1865 during expansion, "a new epoch" was ushered in. Performances included full-length choral-orchestral works of increasing difficulty. Early concerts were given without orchestral accompaniment using soloists from the choir but as expansion proceeded orchestral accompaniments improved until from 1896, the Society was accompanied by the Bradford Permanent Orchestra. It was also necessary during expansion to adjust the workload of the choir in order to ensure that artistic standards were maintained. In 1885, during expansion, the choir took on too much work and was criticized for its unpreparedness. As a consequence, the annual number of concerts was reduced to four or five. By 1906 at maturation, the Society had attained an artistic level such that their Queen's Hall concert was evaluated by the London Press as "first rate" and they were described as "a magnificent body of singers". Throughout the period the performance of the Messiah (often in December and 41 times during the first 50 years) became an institution "to be looked for with the same degree of expectation as the roast beef, plum pudding, and mince pies, of that festive season" and" relied on to replenish the depleted coffers of the treasury" (ibid.: 66, 76, 83, 151, 162, 195, 217, 247-66).

\section{Edinburgh Royal Choral Union (1858-1958) 9}

The majority of the members who formed the Edinburgh Choral Union in 1858 came from the choir of St. Mary's Roman Catholic Church, Broughton St., under the direction of organist, Charles Hargitt, who became the first conductor of the Society. After initial expansion,

9 James Waddell, History of the Edinburgh Choral Union, n.p. [Edinburgh]: printed for the Society by T. and A. Constable, 1908; The Centenary of the Edinburgh Royal Choral Union, 1858-1958, n.p. [Edinburgh]: privately printed by T. and A. Constable, n.d. [1958 or 1959]. As there is much more detailed information on the first half-century (1858-1908), the analysis is primarily based on this period. 
momentum was lost during the change of conductors from Hargitt to James Shaw during 1862-64. Expansion continued under conductors William Howard (1864-66) and his successor Adam Hamilton until about $1881 / 2$ when regression set in. This was followed by rejuvenation and expansion under Thomas $\mathrm{H}$. Collinson from about $1888 / 9$ moving toward maturation in 1908 . Thereafter, the evidence is insufficient to document specific changes in developmental phases. During its latter half-century, however, the Union survived two world wars, a major economic depression, five changes of conductor, and from the evidence of the choral repertoire and performance dates (1905-58) published at is centenary ([1958 or 1959]: 24-47; see also Waddell 1908: 2, 37, 150-59, 163, 164), it is evident that the Union consolidated its position and maturation can reasonably be assumed.

There were changes in rehearsal and performance time over the period. At formation it was envisaged that one weekly rehearsal would be held on Thursdays, from 8:30 p.m.. During expansion, however, a number of alterations in the rehearsal day and time were made. ${ }^{10}$ Extra rehearsals appear to be more numerous until about 1867/8. Over the period from formation to maturation the number of performances per year was reduced with performances planned from the beginning of the season, less impromptu, and by 1886 , the Union formed a shorter concert season (from November or late October to March or early April) than that envisaged at formation (from mid-October until the end of

10 See Waddell, pp. 2, 22, 23, 30, 41, 66, 73, 97, 106, 184, 185, 209, for rehearsal day changes, and pp. 3, 190, 263-281, as well as Centenary pp. 24-47, for concert season changes. Rehearsals for example, were scheduled Wednesdays from 8:45 p.m. in 1860; Friday from 8:30 p.m. on January 3, 1862; Thursdays, from 8:30 p.m. in 1863; Wednesdays from 8:30 p.m. in $1866 / 7$; two weekly rehearsals on Wednesdays from 8:30 p.m. and Saturdays from 7:30 p.m. during the $1867 / 8$ season; one weekly rehearsal on Wednesdays, during the $1872 / 3$ season; two weekly rehearsals on Tuesdays and Saturdays in 1886/7; "extra rehearsals" on Wednesdays in April, 1886, in preparation for the Edinburgh International Exhibition; and an "after season" in $1888 / 9$. 
June). Within the concert season, the annual performance of the Messiah and the New Year's Day Scotch concerts became institutionalized.

Similarly, a consolidation in rehearsal venue and feeder system for the recruitment of new members and response to external competition from other choral organizations is evident. There were five changes in rehearsal venue in earlier expansion but by 1886 the Union had found a "home" in St. George's Hall where rehearsals were still being held in 1908. There were also a variety of performance venues but as expansion progressed, the Music Hall and subsequently McEwan Hall became the principal venue. During expansion in $1864 / 5$ the Union set up a formal training program for members that became institutionalized during the first fifty years, consolidating into a definite season and growing from one to two weekly classes to form the basis for the regular recruitment of singers at the beginning of each season. It also faced external competition from the Tonic Sol-Fa and Solfeggio associations during expansion and met this by cooperating with the Tonic Sol-Fa Association in joint performances and by merging with the Solfeggio Association in 1866.11 The Union membership increased and changed in composition during expansion in the first half-century. There were 33 men at formation in 1858 and a seventy-voice choir augmented for the occasion performed in 1860 but the number of men fell to less than twenty during the $1862 / 3$ season and to ten in the $1863 / 4$ season. In 1864/5 the combined forces of the Society and the Tonic Sol-Fa Association numbered a chorus of 250 which grew to 350 in the following season. There were 333 singers in the 1907/8 season (75 sopranos, 70 altos, 60 tenors, and 78 basses) and 286 singers in 1958 (47 first sopranos, 44 second sopranos, 50 first altos, 40 second altos, 25 first

11 See Waddell, pp. 3, 15, 41, 52, 66, 149, 185, for rehearsal venues; pp. 12-19, $26,28,235$, for major performance venues; pp. $47,66,67,179$, for choir training classes; and pp. 47, 62 for choir relations with the Sol-fa and Solfeggio associations. 
tenors, 14 second tenors, 40 first basses and 26 second basses). The ratio of women members also increased. Whereas there was a shortage of sopranos and altos in $1861 / 2$, later, the Union encountered a problem in recruiting tenors of suitable quality (ibid.: $11,21,24,37,43,48$, 54).

Changes in community interest in the ensemble, the motivation of members, the ensemble's image and aspects of its prestige are also evident. The Union generated community interest by its participation in benefits and services throughout expansion and its civic links were well established by 1908 . Community interest was partly reflected in concert attendance and receipts from Union-sponsored concerts. Waddell has documented receipts and expenditures over the period 1874-87 showing the downturn into regression and indicating the falling off of community support at that time. Certain repertoire, for example the Messiah, was generally well supported, while other performances were an artistic success but, because they were poorly attended, were financially unsuccessful. At first, during formation and early expansion, its social activities were interwoven with the musical performances but these later became institutionalized and formalized in annual picnics and assemblies. Also, the emphasis at formation was on personification (i.e. the building of an ensemble image) exemplified in the drawing up of the 1858 constitution and subsequently during expansion, the 1867 constitution following the merger with the Solfeggio Association. This contrasts with the emphasis on preserving the ensemble's image in 1908; in the concern with musical reviews and the quality of musical performances at that time. The Union's prestige grew throughout expansion and in 1896 the conductor was still seen as an important contributor to the ensemble's achievement and stature. Not only did the Union become increasingly attractive to conductors as evidenced by the applicants for openings in the conductorship, but the list of guest conductors over the period 1908-58 attests to the choir's stature in attracting the notice of internationally acclaimed conductors. As expansion proceeded, the Union was progressively criticized with reference to other British choruses and there were increasing expectations of the 
ensemble in the Press, especially during the period when the Union was sponsoring orchestral concerts under the conductorship of August Manns (1879-87). Over time, the chorus gradually acquired a national reputation. It performed at more prestigious venues with better instrumental accompaniments. This progress was interrupted during regression as the Union received increasingly mixed reviews, experienced deteriorating finances, lost prestige and declined into relative obscurity. With rejuvenation and renewed expansion under Collinson came increasingly more favourable notices of Union performances and an improved financial picture. ${ }^{12}$

The Union's objectives and rules changed over the first half-century. Its initial purpose at formation was the performance of oratorios and

12 Benefits and services in which the Union participated are documented in Waddell, pp. 137, 200, 208, 211, 215, 222, 225, 228, 230, 232, 234, 237, 240, 244, 245, and the Civic Reception given to the Union in its centennial year is described p. 260. Concert receipts and expenditures over the period from $1874 / 5$ to $1886 / 7$ are tabulated p. 195 . The substitution of the Creation for Bach's Magnificat and Dvorak's Spectre's Bride after the failure of Parry's Judith in the 1888/9 season is documented pp. 201, 202, and the popularity of the Messiah is noted pp. 123,199. The first assembly was held in 1861 (p. 25) and by $1873 / 4$ it had become an annual assembly (p.111). The Union constitutions are referred to pp. 3, 4, 73. In 1890 , the Union tried to recover its prestige and image through excellent performances and in the succeeding years to 1908 members worked hard to maintain and improve standards. Compare the mixed reviews from 1878 /9 to $1884 / 5$ (pp. 141, 144, 145, 148, $150-3,155,157,159,161,166,169,173,175,178$ ) with the uniformly good reviews from $1902 / 3$ to $1907 / 8$ (pp. $245,246,248,249,250-4,257,259$ ). The rise, fall, and subsequent rise of the Union's prestige is documented (see pp. $21,54,83,207,232,259,260$ ), and the choir's achievement by 1897 is attributed to the work of Collinson, the conductor (pp. 163, 164, 232). There were 17 applications for the Union's conductorship in 1883 and 19 in 1915 (p. 162; Centenary p. 232). For a list of guest conductors during 1858-1908 see Waddell, pp. 316, 317, and during 1908-1958 see Centenary pp. 24-47. In Waddell, pp. 119, 195, 197, the financial deterioration between $1874 / 5$ and $1886 / 7$ is noted, and the improving financial picture between $1890 / 1$ and 190. 
large choral works. This objective was widened during expansion to include the sponsorship and organization of orchestral concert series in 1867-74 and 1874-87. Although James Waddell mainly attributes the regression that followed in the 1880 s to prevailing economic conditions, the very breadth of the Union's objectives may also have been a contributing factor as a result of its being stretched beyond its means and its original purpose. Rejuvenation came when it subsequently returned to a more specific purpose, namely, the provision of its own choral and choral-orchestral performances. Also, the Union formalized its rules in a constitution at formation and rapidly established an organization more typical of maturation. Although there were several constitutional changes during expansion, notably in $1863,1867,1879$, and 1885 , the major pattern was set by 1867 (ibid.: 2, 3, 4, 41, 73, 113, 138, 179, 190-96).

Artistic standards rose during expansion and deteriorated during regression. For example, the quality of orchestral accompaniments rose over the period 1858-1908. The orchestras were smaller and more uneven during formation and early expansion than in later expansion. When the financial condition of the Union deteriorated during regression, the choir reverted to the use of piano and organ or small string orchestra accompaniment until its finances improved during rejuvenation. By 1908, professional orchestral hw. accom-pa-ni-ment was again used. The choir moved from the performance of partsongs and glees at formation to a preponderance of major choral and choral-orchestral works in later expansion. The list of works performed over the century (1858-1958) provides evidence that there were periods during which programming was more adventurous than at other times. There was a tendency to repeat works in early expansion and to retreat to well-tried favourites, for example Messiah or Elijah during regression. In the 1890s during expansion, the Union was supported by professional musicians of high calibre ${ }^{13}$ and by 1908 was established as

13 At first accompaniments were provided by local amateurs and professional 
the premier choir in Edinburgh. The responsibility for the Union's artistic development principally lay with its conductors and James Waddell's history suggests a clear link between conductor competence and ensemble development phase. Sometimes a lack of competence was evident only by comparison with other conductors. For example, the public dissatisfaction with Hamilton's conducting arose when he was compared to Manns who was concurrently conducting the orchestral concerts, and Collinson's directorship of the Union was contrasted to his predecessor, Hamilton.

\section{South London Choral Association (1869-1890) ${ }^{14}$}

The South London Choral Association was formed by a few members of the Southwark Tonic Sol-Fa Choral Society in 1869. L.C. Venables was chosen as conductor and remained so for 21 years. Rapid expansion followed to 1890 by which time the choir had achieved a regional reputation in London (ibid.: 3, 4, 21, 25, 26).

As expansion proceeded the Association gave more concerts, eventually consolidating the number of appearances at about ten per year. It gave 30 concerts between 1869 and 1874, 69 between 1875 between 1875 and 1880, and 90 between 1880 and 1890 . Performance traditions, for example, an annual Christmas concert (instituted in 1869), also developed early. By 1880 during expansion the Intermediate and Advanced choirs were meeting on Thursday and Friday evenings respectively, in order to meet their performance schedules (ibid.: $5,6,21,22,24$, 26-28).

orchestral musicians (see Waddell, pp. $21,24,35,67,70$ ) but during regression they were provided by piano and organ (pp. 144, 199) or string orchestra (pp. 149, 197, 206). In expansion during the 1890 s, the Union was accompanied by the professional Scottish Orchestra. For repertoire lists see Waddell pp. 281-4 and Centenarypp. 24-45.

14 Eben Lock, History of the South London Choral Association and Institute of Music London: Robert Banks and Son, 1892. 
There were also changes in rehearsal venue, the growth of training classes that provided recruits for the choir (feeder system), and external competition from other established choirs during expansion. The Association met at the Sutherland Chapels School Room at formation. By 1875 it had outgrown its initial rehearsal venue, and the movement to have a permanent "home" culminated in the purchase of the Surrey Masonic Lodge on October 1, 1880, providing accommodation for the elementary classes in which Tonic Sol-Fa was taught and for the intermediate and advanced choirs. ${ }^{15}$ A system of training classes was instituted at formation and continued to provide a steady stream of recruits throughout expansion. Initially, an elementary class consisting of a formal twelve-lesson course leading to an elementary certificate was formed from personal friends of choir members. An hierarchical structure of elementary classes, intermediate and advanced choirs was established four years later in 1873. Early in expansion, in 1871, the Surrey Choir grew jealous of the Association's invasion into its territory. The Association had scheduled a performance of Judas Maccabeus and the Chapel Choir deliberately scheduled their performance of the Creation for the previous week and tried by other means to spoil the Association's performance. This competition only had the effect of spurring the Association on and their performance of Judas Maccabeus was reported to be a musical success.

The membership of the Association grew during early expansion from an initial 46 members at formation (10 sopranos, all women, five altos, one woman and four boys, 13 tenors and 18 basses) to more than double that size by 1872 (56 members in 1870; 100 in 1871; 104 in July, 1872 of whom two had 13 months experience and 20 had seven months experience beyond their first lesson in sol-fa). The choir membership

15 See Lock, pp. 4-6, 9. In his book entitled Choral and Orchestral Societies. $A$ Book of Hints on their Organisation, and Business and Musical Management (3rd edition, enlarged, London: J.Curwen \& Sons, n.d., p. 48), L.C. Venables notes that out of 135 contemporary choirs, 97 did not have an elementary class and of the 36 that did, 20 were Tonic Sol-Fa choirs. 
appears to have stabilized by 1880 with an intermediate choir numbering 160 to 200 singers and an advanced choir averaging 180 singers. Likewise, the elementary classes grew, evidenced by an enrolment of 3232 students in these classes over the period 1869-90 of whom about half (1669) gained their elementary certificates and 656 gained their intermediate certificates. ${ }^{16}$

There were also developments in community interest in the Association, member morale and motivation, choir image and aspects of prestige. During expansion the Association developed an increasingly broad base of community support for, and interest in, its performances. Its participation in soirees and concerts in 1871 , in the competition at the Crystal Palace in 1872, and in the July 1873 competition when it came second in a field of three, helped bring the Association into prominence. It began to "feel its feet" and seek for means of further expansion. Also, the success of its performance at the Surrey Chapel in June, 1871 "fed the enthusiasm of the choir" and as expansion proceeded, not only did morale grow, but the members began to be more involved in the administration of the choir from 1874. They were motivated to attend rehearsals by the periodic reading out of the register. From 1872 , the first of the annual reunions was instituted. A variety of social activities, for example, New Year's parties, summer excursions and cricket matches were held. By 1890 , the Association was still in the process of developing its reputation and defining itself (i.e. personification) and in that year it registered itself as a non-profit company under the Companies Act. While its prestige rose, the focus remained on the conductor, Venables. After its participation in

16 It took a pool of 3232 potential recruits to maintain the intermediate and advanced choir combined strength at approximately 360 (see Lock, op cit., 4-7, 15, 16, 24, 25). During the first decade there were 70 pupils in the first class of 1870,34 in 1871,79 in two classes in 1872, 174 in three classes in 1873,161 in three classes in 1874, 133 in two classes in 1875,175 in one class in 1876, 200 in 1877, 203 in 1878, and 180 in 1879. During the second decade $(1880-90)$ there were 1823 students with one class each year. 
competitions and its performances early in expansion, invitations began to be received from the London West End in 1875/6. There were also engagements at the Surrey Association for the Advancement of Science, Art and Literature and at Crystal Palace, both in 1877. In an 1879 review, reference was made to the rapid rise in popularity that the choir had achieved. This continued in the 1880 s when it participated in a Royal Philharmonic concert (1881) a Festival of the Association of Tonic Sol-fa Choirs (1884) and the Boosey and Hawkes English Ballad concerts (1880-1887). ${ }^{17}$

The Association's values and rules changed during expansion. At formation, its principal objective was an educational one: "the promotion of the study of music by means of the Tonic Sol-Fa Method, especially through the organization of classes and choirs for the practice of vocal music, and the formation of an institute for imparting instruction in other branches of musical education."18 It separated from the Tonic Sol-Fa Association in 1874 during expansion and although it continued to promote the tonic sol-fa sightsinging method, its own interests increasingly took precedence. Also, while a universalistic philosophy governed admission to the elementary classes, a progressively more elitist approach characterized admission to the intermediate and advanced choirs. These values were enshrined in the constitutional rules of admission to the Association's classes and choirs. In the initial constitution considerable power was vested in the conductor but the

17 Lock, op.cit.: 5-8, 12, 15, 18, 19, 21, 26-28, 30, 33. While the Association had a "strong list of patrons" appeals for finanacial support from the public were relatively unsuccessful. Nevertheless, the members responded zealously, using "quarterly collecting cards, ruled for weekly subscription" in order to solicit funds, and along with their friend, taking bonds in order to finance the purchase of the Association building (See Lock, op. cit., 12, 13, 21).

18 The constitution and rules of the South London Choral Association are described in Venables op. cit.: 28-31. Also see Lock op. cit.: 9, 12, 33. 
new constitution and rules drawn up in 1875 reflected the members' wish to participate more fully in the Association's administration and be better represented in its decision-making. With the formation of an advanced choir in 1873, the rules for admission to the choirs were refined. Admission to the intermediate and advanced choirs was now governed by possession of elementary and intermediate certificates, respectively. The Association's rules were further amended in 1890 when it was registered as a non-profit company.

The rising artistic standards of the Association throughout expansion were evidenced in the published reviews of performances (cited in ibid.: 10, 21, 25, 26) at the more prestigious venues, for example, Crystal Palace, St. James's Hall and Albert Hall. In 1874, the Standard critic referred to the Association as "the best body of part-singers the Metropolis affords, with the sole exception of Mr. Henry Leslie's choir"; a Times review of a performance in St. James's Hall, in December, 1878, referred to its first trial "in a wider sphere" as a "decided success"; and in 1881, the Daily Telegraph referred to it as "struggling upwards toward the vacant place " left by the dissolution of Mr. Henry Leslie's choir. The persons mainly responsible for the development of the Association's artistic standards were the conductor, Leonard Venables and his brother George who taught many of the elementary classes and conducted the intermediate choir.

\section{Glasgow Orpheus Choir (1906-1951) ${ }^{19}$}

The Glasgow Orpheus Choir was formed in 1906 when members of the Toynbee House Musical Association which had been under the direction of Hugh S. Roberton since 1901, left the Toynbee Men's Social Club of which it had previously been a part and formed a separate choral

19 Hugh S. Roberton. Prelude to the Orpheus Edinburgh, Glasgow, London: William Hodge and Co., 1946; Hugh S. Roberton and Kenneth Roberton, sel. and ed., Orpheus, with his Lute: a Glasgow Orpheus Choir Anthology, Oxford, London, New York, Paris: Pergamon Press, J. Curwen \& Sons, 1963. 
organization. Under its sole conductor, Roberton, the choir expanded to reach international stature by 1951 . When Roberton announced his retirement in June, 1950, effective for the following summer, the members unanimously voted to close the choir. The cessation phase lasted a year and represents a special case of "truncation", or the cessation of a choir either in expansion or maturation rather than the demise of an ensemble following regression (Roberton, 1946: 19, 40, 43, 44, 57-60; Roberton and Roberton, 1963: 167, 168, Part 9).

By 1906, early in expansion, the choir had established a pattern of March and December performances in Glasgow that by 1951 ran to four successive nights, with audiences aggregating 12,000 and more than 20,000 each season. A defined season had emerged by 1950 such that the last season during cessation was considered to unusually long, from August 29, 1950 to June 16, 1951 (Roberton, op. cit.: 6, 13; Roberton and Roberton, op. cit.: 280).

The choir also performed in progressively more prestigious venues and extended the sphere of its influence through radio broadcasts and national and international tours. The Glasgow Orpheus's first major concert was in St. Andrew's Hall in 1907. This was followed by a visit to London in 1908. Subsequently, there were concerts in the Edinburgh International Festival, Festival Hall in London, Belfast, Dublin, Newcastle, Liverpool, among others, and visits to countries including Ireland, U.S.A., Canada, Sweden, Germany, Holland, Denmark, and Norway

- 1228 concerts in 178 places. Nevertheless, despite its performances elsewhere, the choir cultivated a base of support in Glasgow and gave over 400 concerts there until 1951 (Roberton, op. cit.: 25, 37, 38, 53; Roberton and Roberton, op. cit.: 279, 284, and Appendix 4).

The choir quickly established the numerical strength that characterized it for the remainder of its existence. At formation, it totalled 66 singers 
(19 sopranos, 15 altos, 15 tenors, and 17 basses) and by cessation in 1951, there were 70 singers. 20

While community interest in the choir and its prestige grew during expansion, the focus of its prestige remained on Hugh S. Roberton, the conductor. So closely was the choir's prestige linked with that of its conductor that the President of the Glasgow Orpheus said: "The Orpheus is H.S.R. and H.S.R. is the Orpheus." Indeed, Roberton himself believed that "the conductor is so important as to be almost all-important" to a choir's development, that "choirs that stand out have been nearly all built around the personality of some inspiring leader" (B.B.C. typescript, 1974: f. 7). In this regard it is interesting that the members based their decision to close the choir on the belief that no one else could succeed Roberton and that the choir could not continue without him. They wanted to finish at their pinnacle so that the choir would be remembered at the height of its powers. As one member said: "We are allowing the choir to die in order that it may live."21

Interest in the choir increased as a result of its concert performances and broadcasts. The Scots emphasis, in particular, delighted audiences in the City of Glasgow, throughout Scotland, and internationally. Indeed, the choir came to represent Scotland. Its increasing prestige and international exposure in concert tours and through recordings and B.B.C. broadcasts is well documented. While there was some conflict

20 Roberton had similarly built the Toynbee Choir from 40 or 50 members in 1901 to 80 in 1906 (Roberton, pp. 19, 20, 32, 46). In 1949 there were 31 sopranos, 20 contraltos, 22 tenors, and 27 basses - basically the same forces as at formation (Roberton and Roberton, p. 166).

21 See Roberton and Roberton Appendix 2: "Works performed by the Glasgow Orpheus Choir" (pp. 305-321) and Appendix 3: "Gramophone Records of the Glasgow Orpheus Choir" (pp. 325-7). Their recordings include The World Famous Glasgow Orpheus Choir: Conductor Sir Hugh Roberton EMI Starline, SRS 5124). 
in the Press over the choir's decision to disband, its prestige does not seem to have suffered during cessation. On the contrary, the choir was lauded throughout the year with receptions and banquets in their honour. 22

Notable features of choir values, member cooperation and choice of members over the half-century of the choir's existence are also evident. Initially, when the choir formed a part of the Toynbee Men's Social Club its values were mainly social, but musical values gradually assumed greater importance during Roberton's tenure as conductor from 1901-6 to the point that they eventually collided with those of the club and resulted in the severance of a connection between club and choir. Even though the musical values of the Glasgow Orpheus were important at formation they became even more so during expansion. Roberton's values were enunciated in the choir's journal, the Lute. He valued a choir with spirit, believing that technique was of less value and he had three requisites of a chorister: intellectual perception, desire to express music, and a sense of that beauty that is poetry (matching a sense of spirit and poetry that is music which he thought the conductor should have). Roberton continued to stress the importance of choral tone. He also believed that "young societies are much given to contention" and he attributed this to the malcontents who feel inferior as the choir expands and improves. Indeed, this choir was born out of contention as witnessed by its dramatic departure from the parent organization. Nevertheless, at the formation of the Glasgow Orpheus Choir and early in expansion there was a high degree of cooperation and euphoria among the members that was again evident during cessation when Roberton called on their indulgence in meeting an unusually demanding schedule during their final year. Throughout expansion and

22 See Roberton and Roberton, pp. vii, 284; Celebration: Sir Hugh Roberton B.B.C. Typescript, Wednesday, July 17, 1974, aired 1930-2015, TLN 23/GT 1939H, f. 7. The Glasgow concerts were so popular that tickets for their performances were ballotted (Roberton and Roberton, pp. 167, 168). 
cessation, Roberton sought to engender cooperation by writing to the members in the Lute. Further, personnel and outlook improved as expansion proceeded and he had progressively greater choice of members (Roberton, op. cit.: 21, 30, 40-44; Roberton and Roberton, op. cit.: 6, 30-33, 167, 228, 279-81).

A rise in artistic standards is evident over the period of the choir's existence. In formation and early expansion, Roberton chose simple music gradually moving to more difficult and extensive repertoire; focusing on madrigals, glees, partsongs and folksongs at first, and later broadening to include folksongs of other lands, music of the Roman Catholic and Russian Orthodox churches, English and Italian madrigals and motets, mostly in English or English translation.

\section{Croydon Philharmonic Society (1914-1954) ${ }^{23}$}

The Croydon Philharmonic Society was founded in 1914 as the Croydon Sacred Philharmonic Society and had achieved a national reputation by 1954 . World Wars I and II interrupted its progress but the choir survived these external problems to continue to expand again afterwards (ibid.: 8-11, 13-16, 20, 29, 31-33, 40). Alan J. Kirby remained its sole conductor over the period.

The choir's first performance of the Elijah was followed in 1916 by the Messiah and the first carol concert was given that December. World War I precluded regular choral performances and the choir had to be suspended during the $1917 / 18$ season until the end of the war. Afterwards in 1919 the Society was involved with various concerts and peace celebrations and it had settled down to a regular schedule of performances by 1920. During expansion, the season of four concerts in $1922 / 3$ was reduced to seasons of three concerts in 1928/9 and 1929/30. Later,

23 Henry A. Sharp, Croydon Philharmonic Society: Forty Years of Singing, 1914-1954, Croydon: Croydon Philharmonic Society, 1954. 
the first of the annual Christmas concerts - an institution that became very popular - was given during the $1931 / 2$ season (ibid.: 8-11, 16-18).

In formation and early expansion the Society performed in churches and civic halls, for example, the Parish Church, the West Croydon Congregational Church and the North End Hall (now the Civic Hall), but later it performed in more prestigious venues, for example, Queen's Hall, Royal Albert Hall, and Royal Festival Hall (ibid.: 9, 20, 30, 31, $34,36,38,39)$.

During its first twenty years, the Society membership increased from 75 to 170 singers (the maximum number possible with the restricted concert hall accommodation in Croydon at that time). By 1954 it numbered 192 (62 sopranos, 52 altos, 31 tenors, and 45 basses) (ibid.: $21,46,47)$.

There were also changes in community interest in the Society, its image and prestige throughout expansion. Community interest was present at formation and continued to increase and broaden in base thereafter. The initial meeting to form the Society was chaired by the minister of the Aberdeen Road Congregational Church and subsequently, prominent citizens continued to participate in its affairs and development. Society presidents included: Sir Reuben Barrow, Alderman; Howard Houlder, the Major of Croydon; and G.S. Allen, the Deputy Lieutenant of Surrey. This support was institutionalized in 1946 with the formation of the Croydon Philharmonic Friends' Association whose purpose was to provide financial assistance to the Society. Until 1928, the Society was concerned about defining and identifying itself (i.e. with personification). It was first known as the Croydon Sacred Harmonic Society until 1919 when it changed its name to the Croydon Philharmonic Society. In 1922 it fused with the Symphony to become the Croydon Symphony and Philharmonic Society, and reverted to the Croydon Philharmonic Society in 1925. The fusion with the Orchestra was dissolved in 1928 when the choir was reconstituted as the Croydon Philharmonic Society. Its prestige rose during expansion. By the end 
of 1921 the Society had built up a solid local reputation which it was "determined at all costs to maintain and enhance". It attracted the attention of national critics by its performance of Elgar's Dream of Gerontius in the 1922/3 season and rose from being a very good local musical society to "one to be reckoned with in the wider musical world". Its concerts were subsequently reviewed in the national press, for example, Elgar's The Apostles during the 1930/31 season, in the Daily Telegraph. In 1934 the Daily Telegraph compared the Society to the Yorkshire choirs and after World War II it was considered by one critic to be the best choir in the south of England (ibid.: 8, 10-13, 15, $20,30,35)$.

As well, there were developments in Society values and member cooperation. At formation, its connection with the Church was reflected in its name and repertoire, for example, oratorios. During expansion, however, there was an increasing focus on musical values and secularization reflected in the Society's change of name in 1919 and its widening repertoire. There was also a high level of cooperation among the members in formation and early expansion, for example, in the preparation of a concert venue in the Baths Hall, in May, 1919, necessitating a morning's work to set up the stage and seating, a full afternoon rehearsal and an evening concert. As expansion proceeded, formal social activities were organized to serve the dual purpose of drawing members together and more importantly, bringing in funds to mount future productions (ibid.: 10, 17).

Relatively high artistic standards were evident at the outset, for example, with orchestral accompaniments provided by members of the London Symphony Orchestra (with which Kirby was connected) and soloists of high calibre. The Society subsequently benefitted by a fusion with the Croydon orchestra. Its specialization on the performance of Edward Elgar's works, for example, The Dream of Gerontius in the $1922 / 3$ season, The Kingdom in 1925, among others, as well as the performance of other choral repertoire brought it critical acclaim. Elgar conducted the Society in a performance of The Apostles (with the 
London Symphony Orchestra) in 1933, it participated in a four-day Elgar festival in 1935, gave the first performance of Vaughan Williams' Five Tudor Portraits and subsequently participated in a Promenade concert in 1947 and in the opening of the Royal Festival Hall in 1951. It was also conducted by internationally-known conductors, including Adrian Boult, Thomas Beecham, Malcolm Sargeant and Vaughan Williams. Doubtless, its artistic growth over the period was due in large measure to the solid direction and musical connections of Alan Kirby, its conductor (ibid.: 8, 10-13, 17-21, 30, 32-40, 45).

\section{DISCUSSION}

The evidence presented in the eight historical cases above supports the two propositions outlined at the outset. Discrete phases of formation, expansion, maturation, regression, and cessation are generally recognizable and the specific profile of characteristics for each phase are also more-or-less evident as predicted. This is true to a lesser degree in the case of truncation in the Glasgow Orpheus Choir where the ensemble was prematurely closed to preclude the possibility of regression. The case of the Windsor and Eton Choral Society which regressed to the point of cessation may be a more typical example of cessation conditions.

The support for these notions is, however, uneven. The evidence for formation and expansion is greater than that for maturation and still greater than that for regression and cessation, thereby reflecting the limitations of documentary evidence of the sort on which this study is based. As well, the support for the various temporal, spatial, numerical, causal, ethical, and aesthetic aspects predicted in my earlier article is uneven. Some aspects were not generally evident in the histories, for example, the availability of rehearsal and performance space (the demand and supply over time), the geographic feeder area from which the ensemble draws its members, member morale, motivation and response (whether individual or collective), the source of prestige (whether accruing to the ensemble from a member having joined or vice versa, 
member reference groups, internal competition and cooperation among members. These aspects, among others, could be ascertained by other methods, for example, by descriptive research such as surveys and historical research by means of a study of primary sources including choir records. Certainly, systematic research in each aspect of all the developmental phases is warranted.

A particular concern to choral conductors is their role in ensemble development. In my earlier article, I did not include conductors as a specific element in ensemble development phases. This was based on my observation that conductors would most likely have become actively involved in leading a choir by the time they read my piece. By then it would be too late to speculate on whether they had the requisite musical or leadership aptitude to become conductors. Most conductors were simply trying to do their best; to make whatever contribution they could to an ensemble's development. Implicit in my view of artistic development was the notion that the conductor is the individual most likely responsible for the musical development and achievement of the choir. But to what degree is the conductor a causal influence in an ensemble's development? The case of truncation in the Glasgow Orpheus Choir is especially interesting in this regard. The members' decision to close the choir may well have resulted from their belief (as taught by Roberton) that "the Orpheus is H.S.R. and H.S.R. is the Orpheus" (the view that one could not survive without the other). Might it be that where there is a long-term bond between a founder-conductor and ensemble, there is a critical point in expansion when the ensemble must cut its umbilical ties with its founder and forge ahead under other conductors? Cessation follows if it is unable or unwilling to do this. There was historical precedent for Roberton's view that choirs do not necessarily survive a change in conductor (for example, Henry Leslie's choir in London). Nevertheless, the Huddersfield Choral Society, Glasgow Choral Union, Bradford Festival Choral Society and Edinburgh Royal Choral Union provide examples of choirs that survived a change of conductors even though the association of conductor and choir was longer term. In none of these cases, however, was the association of conductor and 
choir as long as that in the Glasgow Orpheus Choir, nor was it as long an association between the initial conductor and choir. Even in the case of the Windsor and Eton Choral Society in which the founderconductor, Elvey, was associated with the choir for over 40 years, it was not as close a relationship as that between Roberton and the Glasgow Orpheus Choir.

I wonder if the manner of the choir's initial foundation is not also a factor here. The choirs appeared to fall into two groups: those in which the conductor took the active role in forming the choir or was the central personality around which it formed (e.g. the Windsor and Eton Choral Society, Glasgow Orpheus Choir) - a group that might be termed "conductor-formed" choirs - and those in which the members organized the choir and then searched for a conductor (e.g. the Glasgow Choral Union, Bradford Festival Choral Society) - a group that might be termed "member-formed" choirs. My sources were insufficient to categorize all the choirs in this study but in each of the choirs in which the tradition of the conductor having the majority of power held, the histories seemed to focus on the conductor as the major factor in the choir's development, while in those member-formed choirs, the histories appeared to focus on the important contributions of members within the choir. In cases where the choir moved toward regression, a change of conductor generally accompanied rejuvenation (for example, in the case of Collinson's appointment to the conductorship of the Edinburgh Choral Union after dissatisfaction with the choir's decline during Hamilton's regnum). This seemed to confirm the notion that during regression, member unease increasingly focuses on the conductor who becomes a scapegoat on whom blame for the decline can be placed.

Also, the evidence would seem to suggest that the conductor is in large measure responsible for the eminence of the choir; that her or his musicianship and leadership impact significantly on the "amount" of expansion among others. Conductors such as Alan Kirby and Hugh Roberton were able to establish national (and international) reputations 
for their choirs (the Croydon Philharmonic Society and the Glasgow Orpheus Choir, respectively) within 40 years, whereas George Elvey succeeded in establishing only a regional reputation for the Windsor and Eton Choral Society within the same time frame. These questions merit further research.

My earlier article only took account of social factors within the ensemble. It is clear, though, from histories such as the ones consulted for this study, that these choirs were greatly influenced in their formation and subsequent development by social, economic and political factors outside the choir's control and by the particular time and place in which it was founded and developed.24 These external factors also merit systematic investigation as they appear to have an important bearing on the development of amateur ensembles.

If substantiated, the notion of developmental phases is useful for further research into social processes operative in amateur choirs. In my earlier article, I posited a series of recruitment strategies consonant with each developmental phase on the assumption that the process of recruitment would likely by demonstrably different at each phase of development. Similarly, other social processes might be expected to differ between developmental phases. ${ }^{25}$ This opens a line of research in which social processes might usefully be described with reference to developmental phases of amateur choirs; such research would be of

24 For example, see Wilmhurst pp. 3-6, 22-25. External factors included: economic conditions (development, depressions), urban population growth, socio-economic background of the population, musical sophistication of the audience, presence (or absence) of a suitable hall for rehearsal and performance, religious background of the population, war, royal patronage, rise of rival musical organizations, social attitudes to singing, and changes in performance practice (such as women singing alto) among others.

25 The recruitment process is one of 22 social processes which Henry Zentner (Prelude to Administrative Theory, Calgary: Strayer, 1973) has identified as characteristic of all social systems. 
potential practical interest to those concerned with optimizing the development of their ensembles as viable and progressive organizations and in preventing their untimely regression and demise.

\section{REFERENCES}

\section{B.B.C. TYPESCRIPT}

1974: Celebration: Sir Hugh Roberton. (Wednesday, July 17, aired 1930-2015, TLM 23/GT 1939H)

BRUXNER, M.

n.d [Preface dated 1941]: $A$ Hundred Years of Music-Making: A History of the Windsor and Eton Choral Society, 1841-1941. Windsor: Oxley and Son.

CRAIG, R., comp.

n.d. [1944]: A Short History of the Glasgow Choral Union. Glasgow: Robert Maclehose and Co.

\section{GLASGOW ORPHEUS CHOIR}

n.d.: The World Famous Glasgow Orpheus Choir: Conductor Sir Hugh Roberton. EMI Starline, SRS 5124.

JORGENSEN, E. R.

1985: "On the Recruitment Process in Amateur Ensembles," Canadian University Music Review, 6: 293-318.

LOCK, E.

1892: History of the South London Choral Association and Institute of Music. London: Robert Banks and Son.

NATIONAL FEDERATION OF MUSIC SOCIETIES

1984: Register of Members and Handbook, 1984. London: Federation of Music Societies. (Francis House, Francis St., London, SW1P 1DE).

ROBERTON, H.S.

1946: Prelude to the Orpheus. Edinburgh, Glasgow, London: William Hodge and Co. 
ROBERTON, H.S. AND K. ROBERTON, comp. \& eds.

1963: Orpheus with his Lute: A Glasgow Orpheus Choir Anthology. Oxford, London, New York, Paris: Pergamon Press, J. Curwen and Sons Ltd.

SEWELL, G.F.

1907: A History of the Bradford Festival Choral Society from its Formation in 1856 to its Jubilee in 1906. Including Also a Brief Account of the Origin of the Bradford Subscription Concerts and of the Bradford Permanent Orchestra. Bradford: G.F. Sewell.

SHARP, H.A.

1954: Croydon Philharmonic Society: Forty Years of Singing, 1914-1954. Croydon: Croydon Philharmonic Society.

VENABLES, L.C.

n.d.: Choral and Orchestral Societies. A Book of Hints on their Organization, and Business and Musical Management. 3rd ed., enlarged. London: J. Curwen and Sons.

WADDELL, J.

1908: History of the Edinburgh Choral Union. n.p. [Edinburgh]: Printed for the Society by T. and A. Constable.

n.d. [1958 or 1959]: The Centenary of the Edinburgh Royal Choral Union, 1858-1958. n.p. [Edinburgh]: Privately Printed by T. and A. Constable.

WILMHURST, W.L., comp.

n.d. [1936]: Huddersfield Choral Society Centenary Memorial, 1836-1936. Huddersfield: W.H. Cook Ltd.

ZENTNER, $\mathrm{H}$.

1973: Prelude to Administrative Theory. Calgary: Strayer. 